\title{
7. OS ISOTOPIC COMPOSITION AND OS AND Re DISTRIBUTION IN THE ACTIVE MOUND OF THE TAG HYDROTHERMAL SYSTEM, MID-ATLANTIC RIDGE ${ }^{1}$
}

\author{
G.E. Brügmann, ${ }^{2}$ J.L. Birck, ${ }^{3}$ P.M. Herzig, ${ }^{4}$ and A.W. Hofmann ${ }^{2}$
}

\begin{abstract}
Drilling during ODP Leg 158 took place on the active mound of the TAG hydrothermal field on the Mid-Atlantic Ridge. The dominant mineral precipitating from the hydrothermal fluid is pyrite. Its Re and Os concentration and the Os isotopic composition provide constraints on the nature of the hydrothermal fluid circulating in the TAG mound.

The ${ }^{187} \mathrm{Os} /{ }^{186} \mathrm{Os}$ ratios of massive pyrite samples vary from 4.9 to 8.9 . The highest ratios have been observed in the upper part of the sulfide mountain ( $<20 \mathrm{mbsf}$ ) and the lowest in the stockwork zone at $\sim 80 \mathrm{mbsf}$. This range of Os isotopic compositions is likely the result of mixing of seawater with hydrothermal fluid. The Os concentrations are very low, ranging from 0.04 to $4.2 \mathrm{ppt}$, and the massive pyrite zone at the top of the mound is enriched in Os relative to the interior of the hydrothermal system. A hyperbolic relationship between Os isotopic composition and Os concentration reflects the systematic addition of seawater-derived Os to the hydrothermal Os component at stratigraphically shallower levels. From this relationship it is estimated that pyrite precipitating from the hydrothermal fluid contains 0.02 to $0.04 \mathrm{ppt}$ Os provided the ${ }^{187} \mathrm{Os} /{ }^{186} \mathrm{Os}$ value of the fluid ranges from about 1.3 to 4.7 . Because of the great mobility of Os in the high-temperature hydrothermal system, it is assumed that its partition coefficient between pyrite and hydrothermal fluid is $<1$. This implies that the hydrothermal fluid contains more than 0.02 ppt Os.

The occurrence of anhydrite-rich lithologies at $\sim 30-40$ mbsf corroborates that seawater is penetrating the hydrothermal system and contaminating the hydrothermal fluid circulating in the upper part of the mound. This partly explains why the Os of sulfides that precipitated above this level has a strong seawater-like isotopic signature. In addition, the massive pyrite zone of the upper part of the TAG mound formed by accumulation of sulfides derived from chimneys and the fall-out material of the hydrothermal plume above the TAG field. Both sulfide components formed during mixing of seawater and hydrothermal fluid and their Os should also have a distinct seawater component.

These processes, especially the entrainment of seawater, appear to control the distribution of Os and Re within the hydrothermal system. The Os enrichment in the upper part of the mound can be explained if the element is co-precipitated with sulfides or adsorbed on mineral surface during the accumulation of sulfides on the TAG mound. As a significant amount of Os can be dissolved in the hydrothermal fluid, remobilization of Os within the hydrothermal system could lead to further Os enrichment at the top of the mound but to very low Os concentrations in the stockwork zone.

The Re concentrations indicate a distribution opposite to that of Os: the highest concentrations of about 60 ppb have been observed more than $15 \mathrm{mbsf}$, but the concentrations decrease from 50 to $2 \mathrm{ppb}$ in samples from the top of the sulfide mound ( $<15 \mathrm{mbsf}$ ). The behavior of Re appears to be controlled by the redox conditions in the TAG hydrothermal system, which, in turn, could be determined by the relative proportions of oxidized seawater and reduced hydrothermal fluid. Deep within the mound, where the hydrothermal fluid component dominates, Re is rather immobile and becomes concentrated. In the upper part of the sulfide mound where larger quantities of seawater mix with the fluid, however, the redox potential should be more oxidizing, and Re would be more soluble and released to the ocean.
\end{abstract}

\section{INTRODUCTION}

Hydrothermal systems form in the vicinity of constructive plate boundaries, a result of the large temperature gradient between hot oceanic crust and cold seawater. The interaction of the hydrothermal fluid with oceanic lithosphere causes significant changes of the composition of the oceanic lithosphere itself and of the hydrosphere. The circulation of hydrothermal fluid mobilizes chemical components and transports them towards the seafloor-seawater interface where these components are either dissolved in seawater or redeposited on the ocean floor to form massive sulfide deposits (Rona, 1988; Rona and Scott, 1993). Such a sulfide mineralization (3.9 million T of sulfides according to Humphris et al., 1995) is presently forming in the TAG hydrothermal field on the slow-spreading Mid-Atlantic Ridge at $26^{\circ} 08^{\prime} \mathrm{N}$ (Fig. 1) and was the drilling target of ODP Leg 158.

${ }^{1}$ Herzig, P.M., Humphris, S.E., Miller, D.J., and Zierenberg, R.A. (Eds.), 1998. Proc. ODP, Sci. Results, 158: College Station, TX (Ocean Drilling Program).

${ }^{2}$ Max-Planck-Institut für Chemie, Abteilung Geochemie, Postfach 3060, D-55020 Mainz, Federal Republic of Germany. Gerhard@Geobar.mpch-mainz.mpq.de

${ }^{3}$ Laboratoire de Géochimie et Cosmochimie, Institut de Physique du Globe, 4 place Jussieu, 75252, Paris cedex 05, France.

${ }^{4}$ Institut für Mineralogie, TU Bergakademie Freiberg, Brennhausgasse 14, 09596 Freiberg, Federal Republic of Germany.
Several recent studies have monitored the chemical mass flow in hydrothermal systems by using radiogenic isotopes as tracers. In particular, the $\mathrm{Sr}$ isotopic composition is a useful indicator describing the exchange of chemical components during the interaction of hydrothermal fluid with basalt (Hess et al., 1991; Bickle and Teagle, 1992) or the formation of massive sulfide deposits during mixing of hydrothermal fluid with seawater at the seafloor (Chapman and Spooner, 1977). Because of recent improvements in the analytical methods, it is now also possible to use the Re-Os system to monitor hydrothermal processes (Ravizza et al., 1996). Besides the siderophile and chalcophile features of the metals, the main advantage of the Re-Os system is that the different reservoirs controlling the Os budget in seawater and in the oceanic crust have distinct isotopic fingerprints. Thus, the low ${ }^{187} \mathrm{Os} /{ }^{186} \mathrm{Os}$ value of MORBs $(1.1-1.7$; Schiano et al., 1996) and average mantle peridotites (1.055; Snow and Reisberg, 1995) can be readily distinguished from the Os isotopic composition of present-day seawater $\left({ }^{187} \mathrm{Os} /{ }^{186} \mathrm{Os}=8.6-8.8\right.$; Ravizza and Turekian, 1992; Burton et al., 1996) and its riverine input ( ${ }^{187} \mathrm{Os} /$ ${ }^{186}$ Os > 10; Pegram et al., 1994).

For this study, core samples from the active sulfide mound in the TAG hydrothermal field, which was systematically drilled during ODP Leg 158, were analyzed. The objectives were to describe the distribution of trace elements, including Re and Os, and the Os isoto-

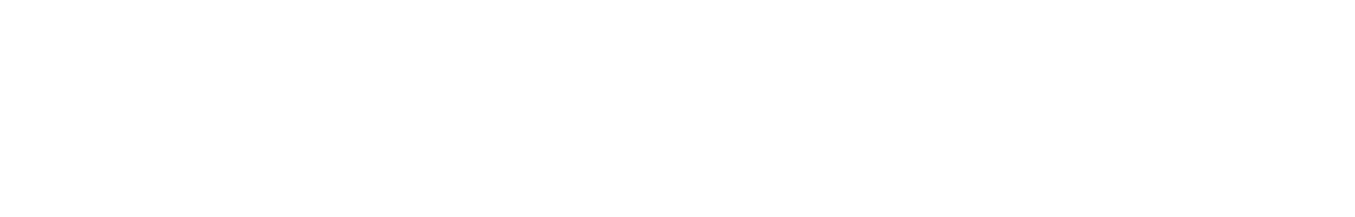




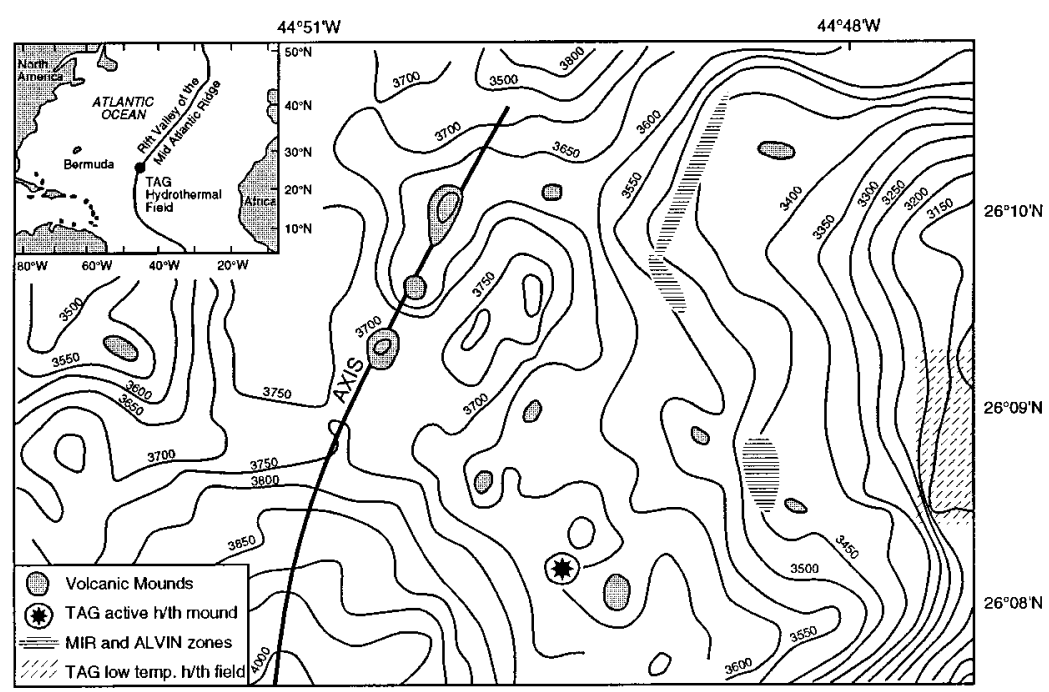

Figure 1. Location of the TAG hydrothermal field and the Leg 158 drill holes.

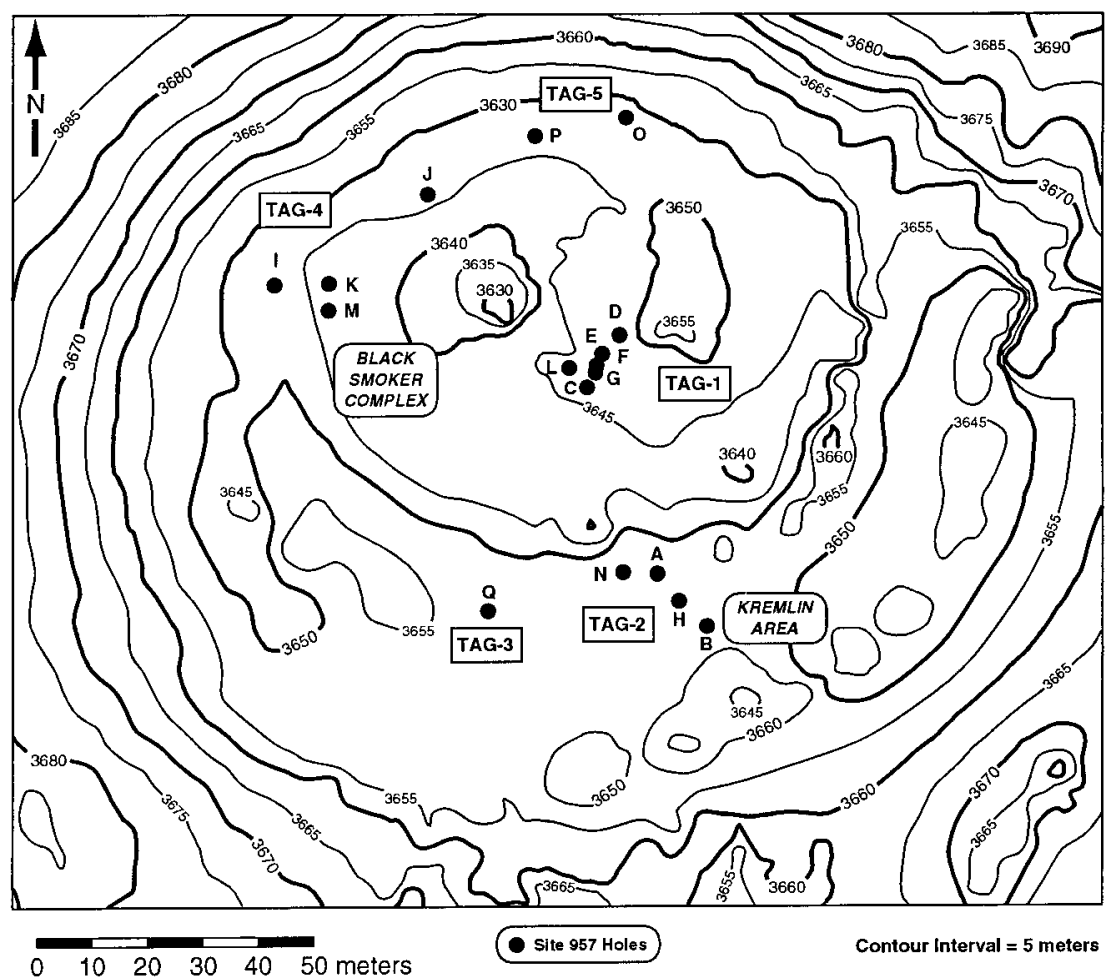

pic composition in an active, mature hydrothermal system and to determine the parameters controlling the mobilization and the transport of these metals during the hydrothermal alteration of oceanic crust.

\section{SAMPLES AND ANALYTICAL METHODS}

The geology of the TAG area and its relict and actively formed hydrothermal sulfide deposits have been described by Rona et al. (1984), Thompson et al. (1985), and Rona et al. (1993). During ODP Leg 158, the active sulfide mound was systematically drilled in 5 different areas (TAG-1 to TAG-5; Fig. 1), which represent different thermal regimes of the hydrothermal system. Different types of hydrothermal fluid are currently emanating from the active TAG mound (Tivey et al., 1995). The Central Black Smoker complex forms the top of the mound (Figs. 1 and 2) and releases a hot, $350-360^{\circ} \mathrm{C}$ fluid. The mineralization associated with this fluid mainly consists of py- rite, marcasite, chalcopyrite, and anhydrite. During Leg 158 the scientific party did not drill directly into the black smoker complex; however, the drilling areas TAG-1, TAG-4, and TAG-5 are very close to it. In the Kremlin area (Fig. 1) there are active "white smokers," which consist of pyrite, sphalerite, and anhydrite. The hydrothermal fluid emanating from the white smokers has a lower temperature of about $260^{\circ}-300^{\circ} \mathrm{C}$. More details on the differences between the black and white smoker fluids, such as $\mathrm{pH}$-value or chemical composition, have been discussed by Tivey et al. (1995).

Mineralogical investigations of the core samples allowed the reconstruction of the present stratigraphic sequence along a southeastnorthwest-striking section across the mound down to a depth of about 130 mbsf (Fig. 2). The results of Leg 158 have been published by Humphris et al. (1995), and only the most important features regarding the constituent rock types will be summarized here. The stratigraphic sequence of the sulfide mound can be divided into four lithologic units, each consisting of various types of breccias. The up- 


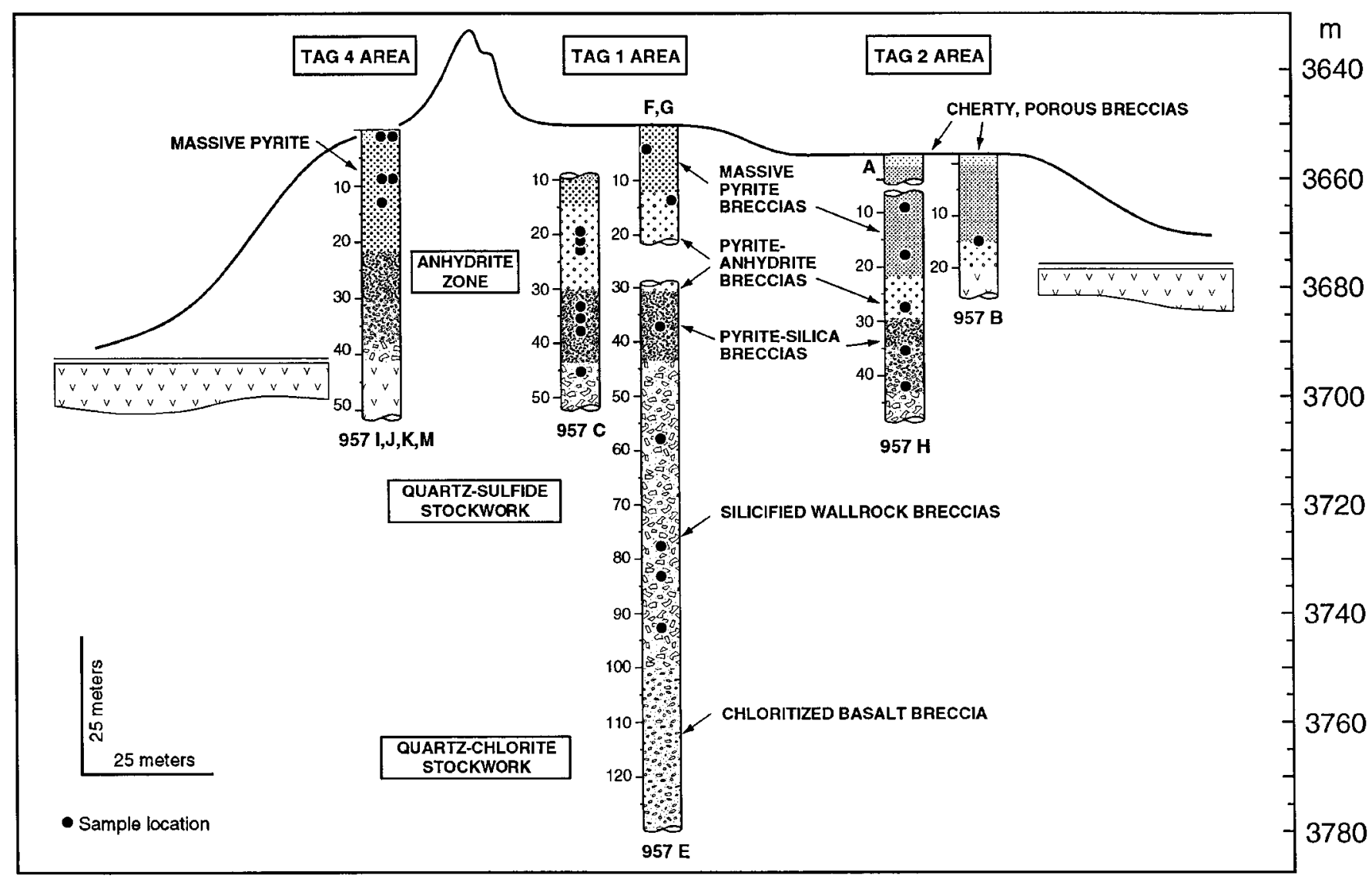

Figure 2. Stratigraphic profile of the TAG sulfide mound and location of the samples analyzed in this study.

per part of the mound (10-20 m) consists of massive pyrite and pyrite breccias. It is underlain by an anhydrite-rich zone with pyrite-anhydrite and pyrite-anhydrite-quartz breccias. These latter rocks probably belong to the stockwork zone of the hydrothermal system, which begins at about 30 to $40 \mathrm{mbsf}$ and is marked with the occurrence of veins of sulfides and quartz and sericitic alteration. With increasing depth, anhydrite becomes less abundant and there is a gradual change from pyrite-silica breccias to sericitised and then chloritized/silicified wallrock breccias. These rocks are lying on basaltic pillow lavas that have been altered to variable degrees. One important result of Leg 158 was the discovery of large amounts of anhydrite within the active TAG mound. As seawater must be the source of sulfate- the sulfur in the hydrothermal fluid dominantly occurs as sulfide-this implies that ample amounts of seawater can penetrate deeply into the hydrothermal system. Because of the retrograde solubility of anhydrite, its presence also implies that the hydrothermal system was active, maintaining a temperature of at least $150^{\circ} \mathrm{C}$ (Humphris et al., 1995).

The locations of the samples analyzed in this study are indicated in Figure 2. We present chemical data from large samples $(>50 \mathrm{~g})$, which had been cut into three slabs. These were used for preparing polished sections, bulk rock chemical analyses, and for separating rock fragments (anhydrite, pyrite, altered basalt) and mineral fractions. The aliquot selected for bulk chemical analyses was first ground in a steel mortar to split size and then in an agate mill to a grain size of $<0.063 \mathrm{~mm}$. Using this powder, major and trace element concentrations and the Os isotopic composition were determined by $\mathrm{X}$-ray fluorescence analysis (XRF) and negative thermal ion mass spectrometry (N-TIMS). The analytical method used to determine the concentration of a specific element is shown in Tables 1 and 2. The XRF data comprise major and trace element analyses of powder pellets that were made at the Technische Universität Freiberg in Germany.
Rhenium and Os concentrations and the Os isotopic composition were determined by N-TIMS on a Finnigan MAT 262 at the MaxPlanck-Institut in Mainz, Germany. The standard techniques described by Creaser et al. (1991) and Völkening et al. (1991) were used, with minor modification made by Birck and Allègre (1994). The Os isotopes were measured as $\mathrm{OsO}_{3}{ }^{-}$by peak switching on a single ion counter, whereas the $\mathrm{Re}$ isotopes were measured as $\mathrm{ReO}_{4}{ }^{-}$ either on one ion counter or, if the concentrations were high enough, simultaneously on faraday cups. Mass fractionation was corrected using an ${ }^{192} \mathrm{Os} /{ }^{188} \mathrm{Os}$ value of 3.08271 and the ${ }^{187} \mathrm{Os} /{ }^{186} \mathrm{Os}$ value was calculated using a ${ }^{186} \mathrm{Os} /{ }^{188} \mathrm{Os}$ value of 0.12035 . The precision $(2 \mathrm{~s})$ is better than $0.4 \%$ for $5 \mathrm{pg}$ of Os.

Rhenium and Os concentrations were determined by isotope dilution using mixed ${ }^{185} \mathrm{Re}-{ }^{190} \mathrm{Os}$ spikes. The Re and Os concentrations and the Os isotopic composition were analyzed on one sample aliquot applying the analytical method described by Birck et al. (1997). The two-step dissolution procedure takes place in a Teflon pressure vessel where 200-500 mg of sample powder and spike solution are first partially dissolved in $\mathrm{HBr}$ and $\mathrm{HF}$. Complete equilibrium among spike and sample are achieved during a second step, where due to the addition of $\mathrm{HNO}_{3}$ and $\mathrm{CrO}_{3}$, Os and Re become oxidized to their highest oxidation states. The Re and Os fractions are separated by solvent extraction methods and purified. The clean-up of the Os fractions was done by the "microdistillation" technique of Roy-Barman (1993); the Re fraction was purified by extracting the metal with $\mathrm{HNO}_{3}$ into Amylol and back-extracting into $\mathrm{H}_{2} \mathrm{O}$.

The total Os blank of the procedure is very low being less than $0.006 \mathrm{pg}$ per gram of sample. The ${ }^{187} \mathrm{Os} /{ }^{186} \mathrm{Os}$ value of the blank increased from 2.5 to 6.5 during the time of analysis. This low blank has likely been achieved because only small amounts of reagents are used in order to dissolve the samples. In addition, the use of new lab ware and cleaning the Teflon beakers and pressure vessels for at least 


\begin{tabular}{|c|c|c|c|c|c|c|c|c|c|c|c|c|c|c|c|c|c|}
\hline $\begin{array}{l}\text { Hole, core, } \\
\text { section }\end{array}$ & Piece & $\begin{array}{l}\text { Depth } \\
\text { (mbsf) }\end{array}$ & $\begin{array}{l}\text { Rock } \\
\text { type }\end{array}$ & $\begin{array}{c}\mathrm{Fe} \\
\text { (wt\%) }\end{array}$ & $\underset{(w t \%)}{S}$ & $\begin{array}{l}\mathrm{SO}_{3} \\
(\mathrm{wt} \%)\end{array}$ & $\begin{array}{l}\mathrm{SiO}_{2} \\
(\mathrm{wt} \%)\end{array}$ & $\begin{array}{c}\mathrm{Cu} \\
(\mathrm{wt} \%)\end{array}$ & $\begin{array}{c}\mathrm{Zn} \\
\text { (wt\%) }\end{array}$ & $\begin{array}{c}\mathrm{Ca} \\
(\mathrm{wt} \%)\end{array}$ & $\begin{array}{l}\mathrm{Al}_{2} \mathrm{O}_{3} \\
(\mathrm{wt} \%)\end{array}$ & $\begin{array}{l}\mathrm{MgO} \\
(\mathrm{wt} \%)\end{array}$ & $\begin{array}{l}\mathrm{TiO}_{2} \\
(\mathrm{wt} \%)\end{array}$ & $\begin{array}{l}\mathrm{Na}_{2} \mathrm{O} \\
(\mathrm{wt} \%)\end{array}$ & $\begin{array}{c}\mathrm{K}_{2} \mathrm{O} \\
(\mathrm{wt} \%)\end{array}$ & $\begin{array}{l}\mathrm{P}_{2} \mathrm{O}_{5} \\
\text { (wt\%) }\end{array}$ & $\begin{array}{l}\text { Total } \\
\text { (wt \%) }\end{array}$ \\
\hline 957B-1R-1 & & 0.1 & Fe-oxide & 20.10 & & & & 8.23 & 2.73 & & & & & & & & \\
\hline 957B-3R-1 & 1 & 14.9 & Ms py & 43.45 & 29.81 & 8.25 & 10.78 & 0.22 & 0.00 & 0.03 & 6.27 & 0.04 & 0.21 & 0.50 & 0.05 & 0.03 & 99.63 \\
\hline $957 \mathrm{C}-7 \mathrm{~N}-2$ & 1B & 21.0 & Sil-py-anh & 23.40 & 12.50 & 14.20 & 35.40 & 0.15 & 0.01 & 9.80 & 0.25 & 0.02 & $<0.01$ & 0.11 & $<0.01$ & 0.02 & 95.86 \\
\hline $957 \mathrm{C}-7 \mathrm{~N}-2$ & $1 \mathrm{~K}$ & 22.1 & Sil-py-anh & 32.00 & 10.30 & 23.60 & 1.29 & 1.42 & 0.06 & 21.90 & 0.05 & 0.04 & $<0.01$ & 0.11 & $<0.01$ & 0.03 & 90.79 \\
\hline $957 \mathrm{C}-7 \mathrm{~N}-2$ & $8 \mathrm{C}$ & 20.5 & Sil-py-anh & 32.50 & 16.10 & 17.00 & 4.80 & 9.90 & 0.03 & 13.50 & 0.28 & 0.03 & $<0.01$ & 0.14 & 0.01 & 0.02 & 94.31 \\
\hline $957 \mathrm{C}-11 \mathrm{~N}-3$ & $5 \mathrm{~B}$ & 34.0 & Sil-py-anh & 40.10 & 24.00 & 12.60 & 2.72 & 10.10 & 0.04 & 7.00 & 0.20 & 0.10 & $<0.01$ & 0.06 & $<0.01$ & 0.02 & 96.93 \\
\hline $957 \mathrm{C}-12 \mathrm{~N}-1$ & $6 \mathrm{~B}$ & 35.5 & Py-anh & 35.60 & 21.70 & 12.40 & 15.50 & 2.91 & 0.05 & 6.70 & 1.10 & 1.03 & 0.01 & 0.04 & $<0.01$ & 0.02 & 97.06 \\
\hline $957 \mathrm{C}-13 \mathrm{~N}-1$ & $17 \mathrm{~A}$ & 38.2 & $\begin{array}{l}\text { Py-sil } \\
\text { Pyl }\end{array}$ & 21.60 & 12.80 & 12.00 & 42.10 & 0.72 & 0.01 & 7.10 & 0.36 & 0.14 & 0.02 & 0.05 & $<0.01$ & 0.02 & 96.92 \\
\hline $957 \mathrm{C}-13 \mathrm{~N}-2$ & $3 \mathrm{C}$ & 38.8 & Sil-py-anh & 35.20 & 17.70 & 16.00 & 17.20 & 0.07 & 0.01 & 9.40 & 0.17 & 0.11 & $<0.01$ & 0.03 & $<0.01$ & 0.03 & 95.92 \\
\hline $957 \mathrm{C}-15 \mathrm{~N}-3$ & 7 & 45.1 & Sil-wall & 24.40 & 17.10 & 9.10 & 41.30 & 1.92 & 0.01 & 4.12 & 0.13 & 0.03 & $<0.01$ & 0.02 & $<0.01$ & 0.02 & 98.15 \\
\hline $957 \mathrm{E}-2 \mathrm{R}-1$ & 4 & 37.1 & Py-sil & 19.90 & 14.50 & 7.20 & 52.50 & 0.49 & 0.00 & 3.24 & 0.30 & 0.14 & 0.01 & 0.08 & $<0.01$ & 0.03 & 98.40 \\
\hline 957E-5R-1 & 5 & 58.8 & Py-sil & 19.10 & 15.30 & 5.10 & 58.10 & 0.46 & 0.00 & 0.96 & 0.29 & $<0.01$ & 0.01 & 0.07 & $<0.01$ & 0.02 & 99.41 \\
\hline 957E-9R-1 & 1 & 77.8 & Ms py & 46.31 & 32.67 & 8.69 & 7.48 & 3.53 & 0.01 & 0.08 & 0.78 & 0.13 & 0.04 & 0.08 & 0.01 & 0.02 & 99.84 \\
\hline $957 \mathrm{E}-10 \mathrm{R}-1$ & 2 & 82.1 & Ms py & 50.10 & 35.30 & 8.10 & 3.60 & 2.29 & 0.01 & 0.04 & 0.18 & 0.06 & $<0.01$ & $<0.01$ & $<0.01$ & 0.02 & 99.70 \\
\hline $957 \mathrm{E}-12 \mathrm{R}-1$ & 5 & 92.1 & Sil-wall & 23.30 & 18.60 & 5.40 & 47.70 & 0.26 & 0.03 & 0.61 & 2.95 & 0.02 & 0.23 & 0.41 & 0.05 & 0.02 & 99.58 \\
\hline $957 \mathrm{~F}-2 \mathrm{~N}-1$ & 4 & 5.7 & Ms py & 50.20 & 35.50 & 8.70 & 2.69 & 1.37 & 0.28 & 0.66 & 0.08 & 0.04 & $<0.01$ & $<0.01$ & $<0.01$ & 0.02 & 99.54 \\
\hline $957 \mathrm{G}-2 \mathrm{~N}-1$ & 1 & 16.5 & Py-anh & 39.60 & 23.60 & 13.80 & 6.00 & 4.34 & 0.05 & 8.50 & 0.34 & 0.04 & $<0.01$ & 0.08 & 0.01 & 0.02 & 96.38 \\
\hline $957 \mathrm{H}-1 \mathrm{~N}-1$ & 14 & 9.4 & Ms py & 31.10 & 12.30 & 20.00 & 1.44 & 9.10 & 0.04 & 17.80 & 0.45 & 0.04 & $<0.01$ & 0.16 & 0.01 & 0.02 & 92.46 \\
\hline $957 \mathrm{H}-3 \mathrm{~N}-1$ & 1 & 17.7 & Ms py & 51.15 & 37.07 & 8.58 & $\begin{array}{l}1.44 \\
1.42\end{array}$ & 0.32 & $\begin{array}{l}.04 \\
1.09\end{array}$ & 0.01 & 0.07 & $<0.01$ & $<0.01$ & $<0.01$ & $<0.01$ & 0.02 & 99.72 \\
\hline $957 \mathrm{H}-5 \mathrm{~N}-2$ & $1 \mathrm{C}$ & 27.8 & Sil-wall & 12.00 & 9.10 & $\begin{array}{l}0.00 \\
4.70\end{array}$ & 67.60 & 0.01 & 0.02 & $\begin{array}{l}0.01 \\
1.79\end{array}$ & 3.10 & 0.08 & $\begin{array}{r}0.01 \\
0.22\end{array}$ & 0.47 & 0.05 & 0.02 & 99.16 \\
\hline $957 \mathrm{H}-7 \mathrm{~N}-1$ & 1 & 35.7 & Py-sil & 23.40 & 18.30 & 5.30 & 52.20 & 0.07 & 0.01 & 0.01 & 0.26 & 0.06 & $<0.01$ & 0.06 & $<0.01$ & 0.02 & 99.69 \\
\hline $957 \mathrm{H}-8 \mathrm{~N}-1$ & 16 & 41.3 & Py-sil & 21.60 & 17.70 & 4.30 & 53.10 & 0.18 & 0.01 & 0.19 & 1.88 & 0.52 & 0.09 & 0.21 & 0.02 & 0.02 & 99.82 \\
\hline $957 \mathrm{I}-1 \mathrm{~N}-1$ & 3 & 9.1 & Ms py & 50.50 & 32.10 & 11.10 & 1.11 & 0.04 & 4.90 & 0.01 & $<0.01$ & 0.02 & $<0.01$ & $<0.01$ & $<0.01$ & 0.02 & 99.79 \\
\hline $957 \mathrm{~K}-1 \mathrm{X}-1$ & 7 & 0.5 & Ms py & 47.20 & 35.40 & 8.20 & 2.18 & 0.08 & 6.50 & 0.01 & 0.07 & 0.03 & $<0.01$ & $<0.01$ & $<0.01$ & 0.02 & 99.69 \\
\hline $957 \mathrm{~K}-3 \mathrm{X}-1$ & 1 & 14.5 & Ms py & 38.20 & 31.00 & 7.60 & 15.40 & 0.18 & 7.30 & 0.01 & $<0.01$ & $<0.01$ & $<0.01$ & $<0.01$ & $<0.01$ & 0.02 & 99.71 \\
\hline $957 \mathrm{M}-2 \mathrm{R}-1$ & 5 & 9.5 & Ms py & 48.60 & 32.30 & 10.00 & 2.03 & 0.14 & 6.60 & 0.01 & 0.07 & $<0.01$ & $<0.01$ & $<0.01$ & $<0.01$ & 0.02 & 99.77 \\
\hline $957 \mathrm{~N}-1 \mathrm{~W}-1$ & 7 & 0.4 & Py-sil & 18.30 & 15.20 & 3.60 & 60.30 & 0.73 & 0.00 & 0.01 & 1.43 & $<0.01$ & 0.08 & 0.19 & 0.03 & 0.02 & 99.90 \\
\hline 957P-6R-1 & 3 & 26.6 & Ms py & 17.82 & 13.31 & 4.62 & 58.41 & 0.01 & 0.00 & 0.02 & 4.55 & 0.03 & 0.29 & 0.67 & 0.08 & 0.02 & 99.83 \\
\hline 957P-11R-1 & 3 & 50.2 & Py-sil & 43.90 & 23.90 & 14.10 & 4.70 & 0.62 & 0.36 & 6.70 & 2.44 & 0.04 & 0.00 & 0.21 & 0.02 & 0.02 & 97.02 \\
\hline
\end{tabular}

Note: Analyses made using XRF; $\mathrm{ms}=$ massive, $\mathrm{py}=$ pyrite, sil $=$ silica, $a n h=$ anhydride, sil-wall $=$ siliceous wallrock . 
Table 2. Re and Os concentrations and the Os isotopic composition of massive sulfides and basalts.

\begin{tabular}{|c|c|c|c|c|c|c|c|c|c|}
\hline $\begin{array}{l}\text { Hole, core, } \\
\text { section }\end{array}$ & Piece & $\begin{array}{l}\text { Depth } \\
\text { (mbsf) }\end{array}$ & $\begin{array}{l}\text { Rock } \\
\text { type }\end{array}$ & $\begin{array}{c}\mathrm{Re} \\
(\mathrm{ppb})\end{array}$ & $\begin{array}{c}\text { Os } \\
\text { (ppt) }\end{array}$ & $\mathrm{Re} / \mathrm{Os}$ & ${ }^{187} \mathrm{Os} /{ }^{188} \mathrm{Os}$ & ${ }^{187} \mathrm{Os} /{ }^{186} \mathrm{Os}$ & $\begin{array}{l}\text { Error } \\
(2 \mathrm{~s})\end{array}$ \\
\hline 957B-1R-1 & & 0.10 & Fe-oxide & 8.2 & 1.01 & 8119 & 1.070 & 8.89 & 0.03 \\
\hline $957 \mathrm{~B}-3 \mathrm{R}-1$ & 1 & 14.90 & Ms py & 2.1 & 0.12 & 17500 & 0.933 & 7.75 & 0.01 \\
\hline $957 \mathrm{E}-9 \mathrm{R}-1$ & 1 & 77.80 & Ms py & 59.5 & 0.07 & 901515 & 0.956 & 7.94 & 0.05 \\
\hline $957 \mathrm{E}-9 \mathrm{R}-1$ & 1 & 77.80 & Ms py & 60.3 & 0.08 & 753750 & 0.962 & 8.04 & 0.04 \\
\hline 957E-10R-1 & 2 & 82.18 & Ms py & & 0.04 & & 0.566 & 4.70 & 0.02 \\
\hline 957E-10R-1 & 2 & 82.18 & Ms py & 63.1 & 0.04 & 1802857 & 0.609 & 5.09 & 0.02 \\
\hline $957 \mathrm{~F}-2 \mathrm{~N}-1$ & 4 & 5.70 & Ms py & 38.3 & 0.12 & 319167 & 0.851 & 7.07 & 0.01 \\
\hline $957 \mathrm{H}-1 \mathrm{~N}-1$ & 14 & 9.44 & Ms py & 35.9 & 0.23 & 156087 & 1.009 & 8.38 & 0.01 \\
\hline $957 \mathrm{H}-3 \mathrm{~N}-1$ & 1 & 17.70 & Ms py & 72.0 & 0.25 & 288000 & 1.041 & 8.69 & 0.04 \\
\hline $957 \mathrm{I}-1 \mathrm{~N}-1$ & 3 & 9.12 & Ms py & 49.2 & 0.29 & 170833 & 1.040 & 8.69 & 0.02 \\
\hline $957 \mathrm{~K}-1 \mathrm{X}-1$ & 7 & 0.45 & Ms py & 39.7 & 0.52 & 76250 & 1.039 & 8.63 & 0.06 \\
\hline $957 \mathrm{~K}-1 \mathrm{X}-1$ & 7 & 0.45 & Ms py & 39.0 & 0.50 & 78020 & 1.035 & 8.60 & 0.04 \\
\hline $957 \mathrm{~K}-1 \mathrm{X}-1$ & 7 & 0.45 & Ms py & 40.0 & 0.49 & 81571 & 1.025 & 8.52 & 0.04 \\
\hline $957 \mathrm{~K}-1 \mathrm{X}-1$ & 7 & 0.45 & Ms py & 36.6 & 0.48 & 76229 & 1.046 & 8.69 & 0.02 \\
\hline $957 \mathrm{~K}-1 \mathrm{X}-1$ & 7 & 0.45 & Ms py & 41.2 & 0.52 & 79154 & 1.034 & 8.59 & 0.03 \\
\hline $957 \mathrm{~K}-3 \mathrm{X}-1$ & 1 & 14.50 & Ms py & 46.8 & 4.20 & 11143 & 1.054 & 8.81 & 0.03 \\
\hline $957 \mathrm{M}-2 \mathrm{R}-1$ & 5 & 9.51 & Ms py & 50.1 & 0.65 & 77077 & 1.003 & 8.38 & 0.07 \\
\hline 957M-9R-1 & 8 & 42.6 & Basalt & 0.97 & 1.85 & 524 & 0.210 & 1.75 & 0.01 \\
\hline $957 \mathrm{M}-10 \mathrm{R}-1$ & 5 & 46.4 & Basalt & 1.04 & 1.77 & 588 & 0.206 & 1.72 & 0.01 \\
\hline
\end{tabular}

Note: Analyses made using N-TIMS; ms py = massive pyrite.

three weeks with $\mathrm{HBr}$ and $\mathrm{HNO}_{3}$ before they have been used for the analyses has further improved the blank. Furthermore, only samples from the TAG hydrothermal field have been analyzed in those Teflon beakers and the very low Os contents in these samples minimized cross contamination, which could be caused by diffusion of $\mathrm{OsO}_{4}$ into and out of the Teflon walls. Despite the low Os blanks the Os concentrations of two samples (158-957E-10R-1 and 158-957E9R-1; Table 2) are so low that the blank contribution could be as high as $30 \%$. The data, however, have not been corrected, because the precise blank is not known. In addition, the isotopic composition of Os in the blank and the samples are very similar, so that the blank correction would not significantly change the measured ${ }^{187} \mathrm{Os} /{ }^{186} \mathrm{Os}$ of these samples.

The Re blank is considerably higher and accounts for 65 to $100 \mathrm{pg}$ per gram of sample. This high blank is partly due to high Re concentrations in $\mathrm{CrO}_{3}$ which has been added during the dissolution of the sample. Because of the high Re concentrations in the samples of this study no blank correction was necessary.

The reproducibility of the analytical technique has been tested by analyzing one sample five times (Sample 158-957K-1X-1, [Piece 7]) and by making duplicate determinations (Table 2). The average Re concentration of Sample 158-957K-1X-1 (Piece 7) is $39.1 \mathrm{ppb}$ with a standard deviation of $1.6 \mathrm{ppb}(4.2 \%)$. The Os analyses of this sample indicate a similar variation (3.6\%) with an average Os content of 0.50 \pm 0.02 ppt. The reproducibility of the ${ }^{187} \mathrm{Os} /{ }^{186} \mathrm{Os}$ value is significantly better with an average value of $8.61 \pm 0.06(0.72 \%)$.

\section{RESULTS}

The results of the chemical and the isotope analyses are summarized in Tables 1 and 2 and the variation of selected element concentrations along a profile through the active mound of the TAG hydrothermal field are shown in Figures 3 and 4.

\section{Variation of Major Elements}

The most abundant mineralogical phases, which build up the various types of breccias of the sulfide mound, are pyrite, anhydrite, and quartz, whereas chalcopyrite $(0-50 \%)$, sphalerite $(<5 \%)$ are minor phases and galena $(<<1 \%)$ only occurs in trace amounts. In addition, rocks from the stockwork zone contain altered fragments of basalt. These phases have different chemical compositions, especially in terms of their $\mathrm{SiO}_{2}, \mathrm{Ca}, \mathrm{Fe}$, and $\mathrm{S}$ contents. Using these chemical parameters, the breccia types can be readily distinguished from each other, and the relative proportions of their constituting components can be semi-quantitatively estimated. Figure 3 shows the variation of $\mathrm{S}, \mathrm{Fe}, \mathrm{Ca}$, and $\mathrm{SiO}_{2}$ along a stratigraphic profile of the hydrothermal system. This profile represents the lithologic sequence as observed in the TAG-1 area, and the locations of the samples from the areas TAG-2, TAG-4 and TAG-5 have been projected onto this depth profile. The major elements do not show systematic variations with depth, as their distribution is determined by the abundance of the rock-forming components. Most samples of massive pyrite and pyrite breccias from the upper part of the sulfide mound have high $\mathrm{Fe}(>40$ $\mathrm{wt} \%)$ and $\mathrm{S}(>30 \mathrm{wt} \%)$ contents but low $\mathrm{SiO}_{2}(<8 \mathrm{wt} \%)$ and $\mathrm{Ca}(<0.1$ wt $\%$ ) concentrations (Table 1; Fig. 3). Anhydrite-rich samples have also high $\mathrm{S}$ and $\mathrm{Fe}$ contents, but the distinctive feature is their high Ca content of more than $5 \mathrm{wt} \%$ (Fig. 3). The rocks of the stockwork zone (pyrite-quartz and silicified wallrock breccias) have high $\mathrm{SiO}_{2}$ contents of more than $40 \mathrm{wt} \%$, but low abundances of $\mathrm{Ca}$ and $\mathrm{S}(<20$ $\mathrm{wt} \%)$.

A few mineralogical descriptions made during Leg 158 on board the JOIDES Resolution do not agree with the observations and chemical composition made in our laboratory. A couple of samples defined as massive pyrite during drilling (Sample 158-957H-1N-1, [Piece 14], Sample 158-957P-6R-1, [Piece 3]) contain anhydrite and quartz, respectively, and this is also reflected by high $\mathrm{Ca}$ and $\mathrm{SiO}_{2}$ contents (Table 1). Similarly, Sample 158-957P-11R-1 (Piece 3), consists mainly of pyrite clasts and anhydrite and it should be defined as pyrite-anhydrite breccia, rather than pyrite-silica breccia. High $\mathrm{Fe}(43.9$ wt $\%)$ and $\mathrm{Ca}(6.7 \mathrm{wt} \%)$ contents, but low $\mathrm{SiO}_{2}$ concentrations $(4.7$ $\mathrm{wt} \%$ ) support this definition. These disagreements emphasize the difficulty of defining sample types. This is due to the extremely heterogeneous mineralogical composition of the core samples, which varies on the centimeter scale. The description of the mineralogy on board the JOIDES Resolution is based on core pieces. However, the samples collected by the shipboard scientific party and analyzed on shore only represent a fraction of these pieces $(2-3 \mathrm{~cm})$, and, therefore, are not always representative for the whole piece. This is why the sample types given in Tables 1 and 2 have not been adjusted and are still those given by Humphris, Herzig, Miller, et al. (1996).

\section{Osmium and Rhenium Distribution in the Tag Hydrothermal System}

Concentrations of Os and Re in samples of massive pyrite and pyrite breccias are shown in Table 2. Rhenium concentrations in the massive sulfides vary from about 2.1 to $72 \mathrm{ppb}$ (Table 2). These abundances are rather high, as they are $2-3$ orders of magnitude higher than those generally observed in other crustal rocks or in oceanic basalts. The highest concentrations (>60 ppb) have been observed 
Figure 3. Variation of the major element concentrations $\left(\mathrm{S}, \mathrm{Fe}, \mathrm{Ca}\right.$, and $\mathrm{SiO}_{2}$ ) along a stratigraphic profile of the active TAG hydrothermal system. The profile corresponds to stratigraphic sequence in the TAG-1 area. Abbreviations: Mass Py $=$ massive pyrite and pyrite breccia; Anh-Py-Sil = anhydrite-pyrite-silica breccia; Py-Sil $=$ pyrite-silica breccia; Sil $. \mathrm{Wr}=$ silicified wallrock breccia.

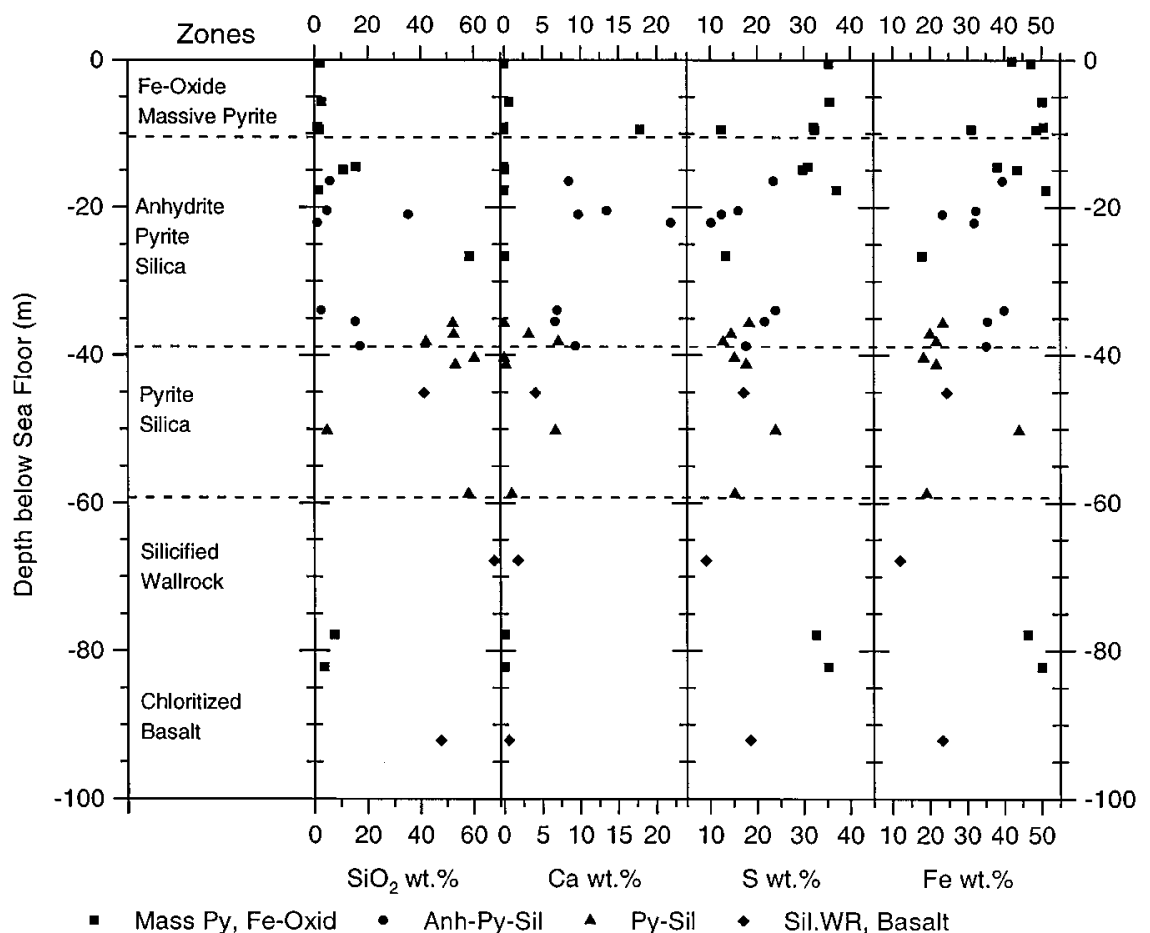

- Mass Py, Fe-Oxid • Anh-Py-Sil ^ Py-Sil • Sil.WR, Basalt

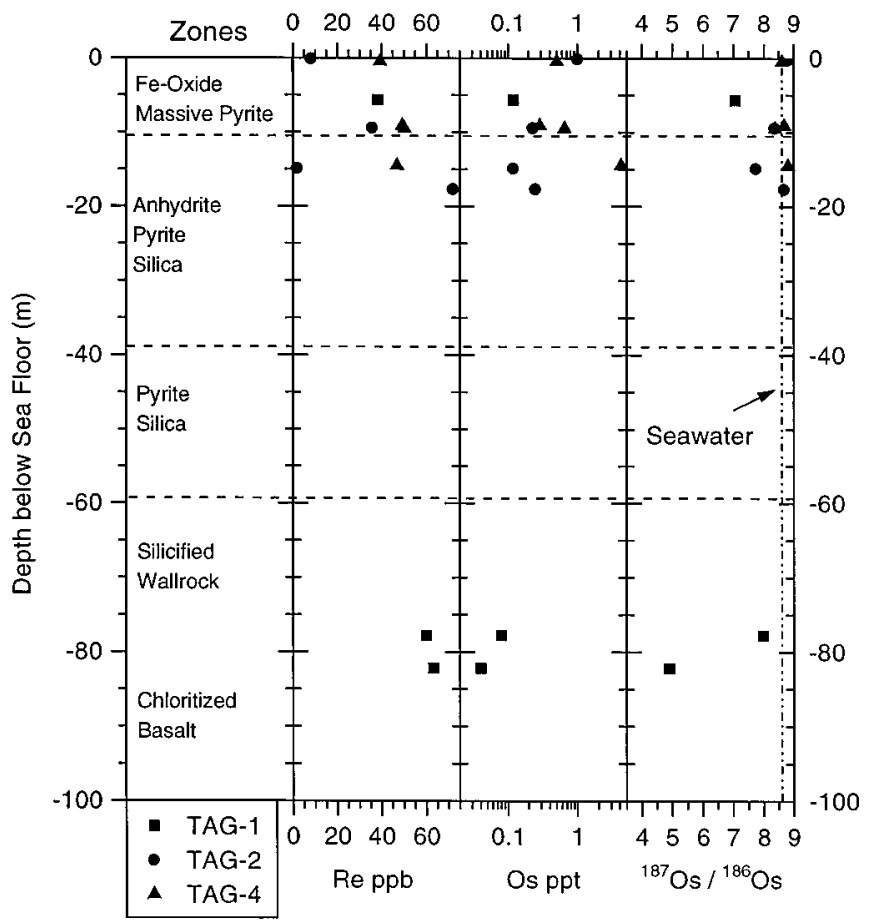

Figure 4. Variation of Re and Os concentrations and the Os isotopic composition of massive sulfides along a stratigraphic profile of the active TAG hydrothermal system.

within the TAG mound ( $>15 \mathrm{mbsf}$ ), but there is a sudden drop from about 60 to $8 \mathrm{ppb} \mathrm{Re}$ in the uppermost $15 \mathrm{~m}$ of the massive pyrite zone (Fig. 4). A few hydrothermal massive sulfides from the Pacific Ocean are also highly enriched in Re (Koide et al., 1986; RoyBarman and Allègre, 1994), however, these data also indicate a large concentration range from more than 100 to $<0.5 \mathrm{ppb}$. Interestingly, metalliferous sediments from the vicinity of the TAG mound have very low Re concentrations of less than $11 \mathrm{ppb}$, and the lowest Re contents $(<1 \mathrm{ppb})$ have been observed in sediments that are believed to represent accumulations of the fallout material from the TAG hydrothermal plume (Ravizza et al., 1996). Thus, the Re distribution is characterized by strong enrichment in sulfides from the interior of the hydrothermal system, lower concentrations in near-seafloor sulfides, and the lowest ones in associated metalliferous sediments.

The Os concentrations are very low ranging only from 0.04 to 4.2 ppt (Table 2). They are 1-2 orders of magnitude lower than those observed in samples dredged on the TAG mound (Ravizza et al., 1996), where fresh sulfide samples from chimneys generally contain 5 to $165 \mathrm{ppt}$ Os, but one sample had an exceptionally high Os content of $3.99 \mathrm{ppb}$. The Os variation shown in Figure 4 suggests that the stockwork zone has the lowest Os concentration $(<0.1 \mathrm{ppb})$, that increases toward the top of the sulfide-rich zone at the top of the mountain (Fig. 4). Thus, the Os distribution indicates a trend opposite to that observed for Re. This appears to be a general feature of the Os distribution, as the oxidized samples from Ravizza et al. (1996) also have higher Os concentrations than the fresh sulfide material. Even higher abundances, 200-500 ppt Os, are found in metalliferous sediments near the margin of the TAG mound (Ravizza et al., 1996). This distribution pattern and the high Os concentrations in some sulfide chimneys suggest that the hydrothermal fluid mobilized Os. In addition, Os appears to become further transported and redeposited by mass wasting and scavenging of seawater derived Os as indicated by the high concentrations and high ${ }^{187} \mathrm{Os} /{ }^{186} \mathrm{Os}$ in the surrounding sediments (Ravizza et al., 1996).

\section{Isotopic Composition of Os in Massive Sulfides}

The measured ${ }^{187} \mathrm{Os} /{ }^{186} \mathrm{Os}$ value in the massive sulfide samples varies from 4.7 to 8.9 (Table 2). This range overlaps with the data from Ravizza et al. (1996) for sulfide-rich rocks $\left({ }^{187} \mathrm{Os} /{ }^{186} \mathrm{Os}=1.3-\right.$ 8.7). In both studies the highest ${ }^{187} \mathrm{Os} /{ }^{186} \mathrm{Os}$ ratios agree with or are slightly lower than the seawater value. This suggests that the Os in samples from the TAG-2 and TAG-4 areas $\left({ }^{187} \mathrm{Os} /{ }^{186} \mathrm{Os}>8.0\right)$ is mainly derived from seawater.

The measured Os isotopic compositions of two samples from the stockwork zone are distinct from seawater, but there is also a large difference between them despite their being recovered only about 5 
$\mathrm{m}$ apart in the same bore hole. Sample 158-957E-9R-1 ([Piece 1], $77.8 \mathrm{mbsf}$ ) has a high ${ }^{187} \mathrm{Os} /{ }^{186} \mathrm{Os}$ value of 7.99 . This ratio suggests that a large proportion of Os in this sample is also derived from seawater and implies that seawater is even penetrating the stockwork zone of the hydrothermal system, some $80 \mathrm{~m}$ below the seafloor. The other sample (158-957E-10R-1, [Piece 2], $82.18 \mathrm{mbsf}$ ) has a ${ }^{187} \mathrm{Os} /$ ${ }^{186}$ Os value of 4.9 , which is the lowest ratio observed in this study. This value lies within the range of isotopic compositions of altered oceanic basalts but is higher than that of MORB (Table 2) and oceanic peridotite (Snow and Reisberg, 1995; Ravizza et al., 1996).

The conclusions drawn above are valid if the measured ${ }^{187} \mathrm{Os} /$ ${ }^{186} \mathrm{Os}$ is similar to the initial Os isotopic composition. Because of the very high Re/Os value of several samples (>100000; Table 2) ${ }^{187} \mathrm{Os}$ ingrowth could change the ${ }^{187} \mathrm{Os} /{ }^{186} \mathrm{Os}$ value of the samples during a relatively short interval of time. Nevertheless, the measured ${ }^{187} \mathrm{Os} /$ ${ }^{186}$ Os data in Table 2 have not been corrected. In order to calculate the amount ${ }^{187} \mathrm{Os}$ added by ${ }^{187} \mathrm{Re}$ decay the time integrated average ${ }^{187} \mathrm{Re}$ content of a sample has to be known. Because of the episodic nature and the still ongoing hydrothermal activity within the TAG mound, this concentration cannot be precisely estimated. If the high Re/Os value in pyrite proves to be typical for hydrothermal massive sulfide deposits on land, however, Re decay would be an important tool to determine the age of ancient ore deposits. There is evidence, though, that the initial ${ }^{187} \mathrm{Os} /{ }^{186} \mathrm{Os}$ value of the massive sulfide samples from the TAG mound did not significantly differ from the measured value, because the distribution of Re and Os in the TAG mound reflects very young processes which likely lasted just for the last 50 years. This is indicated by the presence of anhydrite, which must have formed during the present period of hydrothermal activity, which began just 50 years ago, after a hiatus of about 5000 years (Lalou et al., 1993). This young age precludes any notable ${ }^{187} \mathrm{Os}$ ingrowth despite the large $\mathrm{Re} /$ Os ratios. For example, the ${ }^{187} \mathrm{Os} /{ }^{186} \mathrm{Os}$ of the samples with the highest Re/Os ratios (Samples 158-957E-9R-1 and 158-957E-10R-1; Table 2) would have insignificantly changed from 8.04 to 7.98 and 5.09 to 5.07 , respectively, during the last hundred years.

Additional evidence that the measured Os isotopic ratios should be similar to the initial ${ }^{187} \mathrm{Os} /{ }^{186} \mathrm{Os}$ value is that even presuming an age of 10 to 20 ka cannot explain the rather constant ${ }^{187} \mathrm{Os} /{ }^{186} \mathrm{Os}$ value in most samples from the TAG mound, because of the large variation of the Re/Os ratio. For example, the measured Os isotopic compositions of Samples 185-957H-3N-1 (Piece 1), and 158-957K-3X-1 (Piece 1), are very similar, but they have very different $\mathrm{Re} / \mathrm{Os}$ ratios (Table 2). If their initial ${ }^{187} \mathrm{Os} /{ }^{186} \mathrm{Os}$ value was initially much lower, for example 1.1, reflecting the composition of fresh MORB, then the present ${ }^{187} \mathrm{Os} /{ }^{186} \mathrm{Os}$ value would vary between 1.9 and 52.7 , if the samples were $20 \mathrm{ka}$. Even assuming an age of only $5 \mathrm{ka}$ would cause a ${ }^{187} \mathrm{Os} /{ }^{186} \mathrm{Os}$ variation by a factor of three, which has not been observed in our data set. Therefore, the rather constant ${ }^{187} \mathrm{Os} /{ }^{186} \mathrm{Os}$ values in samples with very different Re/Os ratios can only be explained if the samples were formed very recently $(<1000 \mathrm{yr})$, which leaves insufficient time for significant ${ }^{187} \mathrm{Os}$ ingrowth.

\section{DISCUSSION}

\section{Os as a Monitor of Mixing Between Hydrothermal Fluid and Seawater in the TAG Hydrothermal System}

The isotope composition of Os is an important tool to identify the source of Os in the different lithologic units of the TAG hydrothermal system. It also provides further insight into the physical and chemical processes involved during Os mobilization. The contributions of seawater and oceanic lithosphere can be estimated according to their different isotopic characteristics, as discussed earlier. Meteoritic input, which has an Os isotopic characteristic similar to that of mantle peridotites, can be ignored because of the sulfide mound's young age (<20 ka; Lalou et al., 1993).
If ${ }^{187} \mathrm{Os}$ ingrowth can be ignored as implied by the discussion above, the different isotopic compositions of Os observed at the top and within the mound must be a result of the interaction of processes forming the different lithologic units. The massive sulfide samples analyzed in this study either represent direct precipitates from the hydrothermal fluid within the mound and at the seawater-seafloor interface, or they could be complex agglomerates of several pyrite generations (Samples 158-957H-1N-1 [Piece 14], and 158-957H-3N-1 [Piece 1]; Table 2). Two phenomena eventually gave rise to the sulfide-rich upper part of the TAG mound: the construction and erosion of sulfide chimneys and the fallout of the hydrothermal plume of black "smoke" above the hydrothermal site. In addition, the geochemical features induced by these processes might be overprinted by ongoing circulation of hydrothermal fluid. Sulfide chimneys form at the seafloor where hot fluid exits the ocean floor and mixes with cold seawater. Mainly as a result of the sudden temperature decrease of the hydrothermal fluid and the contemporaneous heating of seawater, sulfides and sulfates become insoluble and precipitate, thereby forming the edifice of chimneys. As the chimneys grow, they become gravitationally unstable and fall to the ground to form the sulfide deposit on the ocean floor. Fallout from the hydrothermal plume will enhance the sulfide accumulation. At TAG, the hydrothermal fluid is buoyant relative to seawater and rises up the water column. During the uprise, the fluid is cooled as a result of the entrainment of cold seawater, and a buoyant plume containing insoluble iron sulfide forms above the mound. Because of the higher density of the iron sulfides, they settled down to the sulfide mound and its surroundings. During both processes, Os dissolved in seawater could be concentrated in the hydrothermal sulfides if it is co-precipitated with iron sulfides or becomes adsorbed on mineral surfaces. These processes can explain the seawater-like ${ }^{187} \mathrm{Os} /{ }^{186} \mathrm{Os}$ ratios in samples from the massive pyrite zone and some chimney sulfides (Ravizza et al., 1996). However, the involvement of seawater is less obvious in some chimney sulfides from the TAG mound and from other occurrences along the East Pacific Rise, which contain high Os concentrations and are mainly derived from the oceanic crust or mantle (Ravizza et al., 1996; Roy-Barman and Allègre, 1994).

The processes outlined above signify that the isotopic composition of Os observed in the different zones of the TAG hydrothermal system should be controlled by the extent of mixing of hydrothermal fluid with seawater. Indeed, in diagrams such as ${ }^{187} \mathrm{Os} /{ }^{186} \mathrm{Os}$ vs. Os concentration (Fig. 5A) or ${ }^{187} \mathrm{Os} /{ }^{186} \mathrm{Os}$ vs. $1 / \mathrm{Os}$ (Fig. 5B) all samples plot close to a hyperbolic curve and a straight line, respectively, which commonly is interpreted to reflect mixing of two components. The high Os end-member has the isotopic signature of seawater, whereas the low Os end-member represents the hydrothermal fluid. In addition, this curve indicates a systematic stratigraphic variation. The samples from the deepest part of the hydrothermal system tend to have the lowest, whereas samples from the top of the mound have the highest Os contents and isotopic compositions (Fig. 4). Thus, the trends observed in Figure 5 reflect the exchange of hydrothermal and seawater Os, and could indicate the entrainment of increasing proportions of seawater relative to the amount of hydrothermal fluid at stratigraphically shallower levels.

The increase of the ratio of seawater to hydrothermal fluid in the upper part of the TAG mound can be explained by two mechanisms. First, because of the strong hydrothermal venting in the area of the Black Smoker Complex, seawater from the water-saturated host rock is drawn into the hydrothermal system. A preferred zone where seawater could penetrate the system would be a tectonically weak area such as the base of the massive sulfide deposit (i.e., the paleo-seafloor). Indeed, it appears that it is this interface (30 to $40 \mathrm{mbsf}$ ) where the anhydrite-rich zone has been formed in the TAG mound (Fig. 2). If this is a zone of major seawater penetration, the hydrothermal fluid above this horizon could be strongly contaminated and the isotopic composition of Os in pyrite precipitating from this fluid would have 

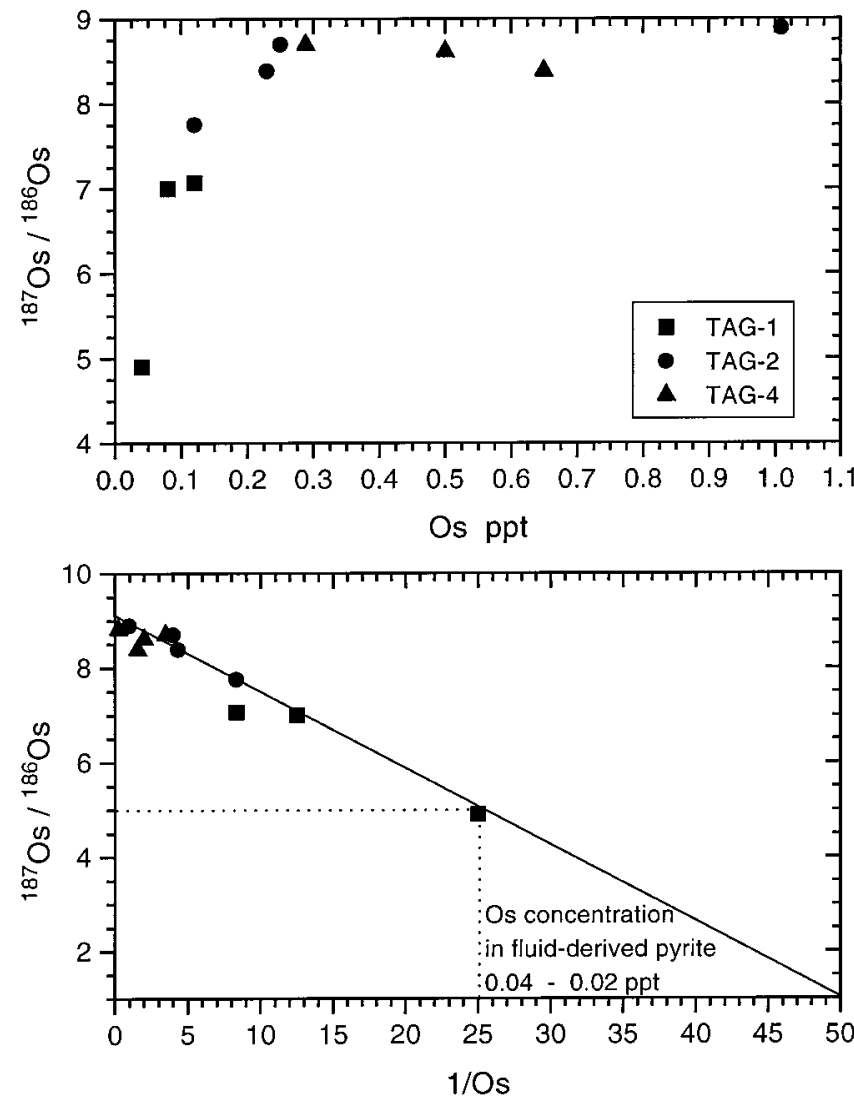

Figure 5. Relationship between the Os isotopic composition and the Os concentrations reflects the exchange of Os between seawater and the hydrothermal fluid. Top: ${ }^{187} \mathrm{Os} /{ }^{186} \mathrm{Os}$ vs. Os: the hyperbolic curve suggests addition of seawater Os to the hydrothermal fluid. Bottom: ${ }^{187} \mathrm{Os} /{ }^{186} \mathrm{Os}$ vs. 1/Os: depending on the ${ }^{187} \mathrm{Os} /{ }^{186} \mathrm{Os}$ value (1.3-4.9) pyrite precipitating from the hydrothermal fluid contains $0.02-0.04$ ppt Os.

a seawater-like signature. This process assumes, however, that seawater does not lose Os because of adsorption or reaction with rocks of the oceanic crust on its way from the seafloor to the hydrothermal system. The second process involves the formation of the massive pyrite zone by accumulation of sulfides from chimneys and from fallout material of the hydrothermal plume. Both sulfide fractions form when the fluid leaves the seafloor and mixes with seawater. It is obvious that much more seawater is involved during this process than in the interior of the hydrothermal system. These processes can also explain the enrichment of Os towards the top of the mound, as Os could be added with the sulfides accumulating on top of the mound. Further concentration of Os could be expected if the fluid circulating in the sulfide mound is able to remobilize Os precipitated at earlier stages of the evolution and can transport it towards the seafloor.

Assuming that the hydrothermal fluid and pyrite equilibrated, the linear relationship between ${ }^{187} \mathrm{Os} /{ }^{186} \mathrm{Os}$ and $1 / \mathrm{Os}$ can be used to predict the Os concentration of pyrite precipitating from the hydrothermal fluid (Fig. 5B) provided there is some constraint on the isotopic composition of the fluid. According to the model presented above the isotopic composition of Os of Sample 158-957E-10R-1 (Piece 2) represents the closest analog of the hydrothermal fluid. Yet, the ${ }^{187} \mathrm{Os} /$ ${ }^{186}$ Os value of the fluid is not well defined, because it is not known whether this sample also contains seawater derived Os. The mass balance calculation suggests that if the ${ }^{187} \mathrm{Os} /{ }^{186} \mathrm{Os}$ value of Sample 158957E-10R-1 (Piece 2) represents the isotopic composition of the hydrothermal fluid, the pyrite precipitating from this fluid contains 0.04 ppt Os (Fig. 5B). This estimate is an upper limit if the pyrite of this sample precipitated from a fluid that was already contaminated with seawater. The lowest ${ }^{187} \mathrm{Os} /{ }^{186} \mathrm{Os}$ value that could be representative for a TAG hydrothermal fluid is 1.3 and has been observed in a chimney sample from the TAG mound (Ravizza et al., 1996). If this is the isotopic signature of the fluid, then pyrite should contain about 0.02 ppt Os (Fig. 5B), which represents a minimum estimate.

In principle, it is possible to calculate the Os content of the hydrothermal fluid using the partition coefficient of Os between pyrite and hydrothermal fluid $\left(D_{P y / F l}\right)$. Although this coefficient is not known, some observations let one assume that it should be smaller than 1 . Ravizza et al. (1996) found low ${ }^{187} \mathrm{Os} /{ }^{186} \mathrm{Os}$ values of 1.3 and high Os concentrations in sulfides from chimneys forming on the TAG mound. This can only be explained if Os can be leached and mobilized from crustal rocks by the hydrothermal fluid and little of the dissolved Os is lost during the precipitation of pyrite within the hydrothermal system. The very low Os concentrations found during this study in the massive sulfide samples support that very little Os is precipitated. The basalt from the TAG area contain about 1 ppt Os (Table 2). Thus, they contain more Os than the samples from the stockwork zone. This also implies that during the basalt-fluid interaction Os was concentrated in the fluid and not in the residue. These observations all demonstrate that Os behaves as a highly mobile element during high-temperature alteration of the oceanic crust and that $D_{P y / F l}$ of Os is probably smaller than one. This implies that the hydrothermal fluid from the TAG hydrothermal system contains at least 0.02 ppt Os.

\section{Redox Conditions Control the Redistribution Within the Hydrothermal System}

In seawater, Re displays a generally conservative behavior as the concentration is about $44 \mathrm{pmol} / \mathrm{kg}$ (normalized to $35 \%$ salinity) in both the Atlantic and Pacific Oceans (Colodner et al., 1993). The high Re solubility is likely controlled by the stability of the perrhenate ion $\left(\mathrm{ReO}_{4}^{-}\right)$as this anion is the dominant species in seawater according to thermodynamic calculations (Koide et al., 1986; Brookins, 1986). However, as Koide et al. (1986) pointed out, it can be reduced by hydrogen sulfide to the far less soluble tetravalent state, which led these authors to suggest that $\mathrm{Re}$ is a sensitive indicator of reducing conditions. This is, for example, supported by the strong Re enrichment ( $\sim 0 \mathrm{ppb}$ ) in anoxic bottom sediments of the Black Sea (Anbar et al., 1992) compared to low Re concentrations of less than $0.3 \mathrm{ppb}$ in pelagic sediments (Koide et al. 1986; Colodner et al., 1993). Ultimately, in reducing sediments, Re seems to be associated with pyrite (Colodner et al., 1993).

As previously outlined, the mixing of seawater and hydrothermal fluid appears to be a major process controlling the distribution of Os. These two media have rather different oxygen fugacities. The presence of $\mathrm{H}_{2} \mathrm{~S}(0.4-3.5 \mathrm{mM})$ and pyrite precipitation record the low oxygen fugacity of the hydrothermal fluid $\left(\log f\left(\mathrm{O}_{2}\right)=-27--29\right.$; Tivey et al., 1995), whereas, for example, the stability of sulfate indicates the oxidized nature of seawater. We suggest that the Re distribution in the TAG hydrothermal mound is governed by the redox conditions in the hydrothermal system, which in turn could be controlled by the relative proportions of oxidized seawater and reduced hydrothermal fluid present in different parts of the mound. Only minor amounts of anhydrite have been observed below $40 \mathrm{mbsf}$ and the isotopic composition of Os has already suggested a smaller amount of seawater entrainment. This implies that the lower, reduced part of the stockwork zone could represent a Re sink, where this element is concentrated with the precipitates of the hydrothermal fluid. However, it must be considered that under these conditions the Re solubility in the fluid is likely very low, too. The Re enrichment in this part of the mound, therefore, cannot necessarily be explained by a onestep precipitation mechanism. It can be achieved, however, assuming a high fluid/rock ratio (i.e., enduring, continuous circulation of fluid accompanied by precipitation of Re with sulfides).

Larger amounts of seawater penetrating into the upper part of the mound could cause more oxidized conditions; hence, Re could become more soluble in the fluid and less concentrated in sulfides pre- 
cipitating in this part of the mound. The best evidence to support this concept is that very low Re concentrations have been found in the most oxidized samples, which are sulfide/iron-oxide-rich sediments on the top of the sulfide mound (Sample 158-957B-1-R1; Table 2; Ravizza et al., 1996)). Thus, as for Os, the Re distribution in the hydrothermal system appears to be ultimately controlled by the relative amount of seawater that has been mixed with the hydrothermal fluid within the mound and that has been involved during the accumulation of sulfides on the top of the sulfide mound.

\section{SUMMARY}

Drilling during ODP Leg 158 revealed that the active sulfide mound of the TAG hydrothermal field on the Mid-Atlantic Ridge comprises a sulfide lens and an underlying stockwork zone, both of which consist of various types of heterogeneous breccias. Humphris et al. (1995) distinguished 4 different lithologic units, from the top to the base:

1. A zone consisting of massive pyrite and massive pyrite breccias;

2. A zone consisting of anhydrite-pyrite and anhydrite-pyritesilica breccias;

3. A zone consisting of silicified wallrock breccias; and

4. A zone consisting of variably altered oceanic basalts.

The breccias are made up of variable amounts of pyrite, anhydrite, quartz, and fragments of altered basalt. The relative proportions of these four components can be estimated by using four chemical parameters $\left(\mathrm{S}, \mathrm{Fe}, \mathrm{Ca}\right.$, and $\left.\mathrm{SiO}_{2}\right)$.

Pyrite is the most abundant sulfide mineral and occurs throughout the hydrothermal system. It is the dominant mineral precipitating from the hydrothermal fluid during conductive cooling or resulting from the entrainment of cold seawater into the TAG mound. This explains why the Re and Os distribution, and the Os isotopic composition in massive pyrite samples is an important tool to monitor the evolution of the TAG hydrothermal system.

The measured ${ }^{187} \mathrm{Os} /{ }^{186} \mathrm{Os}$ ratios of massive sulfides from the upper part of the sulfide mound ( $<20 \mathrm{mbsf}$ ) vary from 7.1 to 8.9 and are very similar to or slightly lower than the present seawater value. As the metal distribution in the TAG mound appears to be controlled by young ( $<50$ years) and still ongoing processes the measured ${ }^{187} \mathrm{Os} /$ ${ }^{186} \mathrm{Os}$ and the initial isotopic composition should be very similar. This implies that most of the Os in these samples is derived from seawater and has been co-precipitated with iron sulfides that formed during the mixing of hydrothermal fluid and seawater and accumulated at the surface of the TAG mound. The ${ }^{187} \mathrm{Os} /{ }^{186} \mathrm{Os}$ ratios of massive sulfide samples from the stockwork zone range from 4.9 to 8.0. The high value indicates that seawater is penetrating deep into the hydrothermal system. The ubiquitous occurrence of anhydrite also indicates the presence of seawater in this zone of the hydrothermal system. The low ${ }^{187} \mathrm{Os} /{ }^{186} \mathrm{Os}$ value lies within the range defined by seawater $(8.6)$ and oceanic lithosphere $(\sim 1)$, and is also similar to ${ }^{187} \mathrm{Os} /{ }^{186} \mathrm{Os}$ values of altered oceanic basalts. Hence, the relatively low ${ }^{187} \mathrm{Os} /{ }^{186} \mathrm{Os}$ value could resemble the isotopic signature of the hydrothermal fluid. Alternatively, it can be explained if one assumes that the Os in this sample is derived from two components: Os dissolved in seawater and Os that has been mobilized in the oceanic lithosphere by the hydrothermal fluid.

There appears to be a stratigraphic control on the isotopic composition of Os, because the lowest ${ }^{187} \mathrm{Os} /{ }^{186} \mathrm{Os}$ values have been found deep within the hydrothermal system (>80 mbsf) and the highest ${ }^{187} \mathrm{Os} /{ }^{186} \mathrm{Os}$ ratios tend to be in the upper part of the massive pyrite zone $(<20 \mathrm{mbsf})$. This signifies that the contribution of seawaterderived Os diminishes as one goes from the top of the sulfide mound toward the interior of the hydrothermal system. The occurrence of anhydrite-rich lithologies at $\sim 30-40$ mbsf indicates that seawater is penetrating the hydrothermal system. This implies that the hydrothermal fluid becomes contaminated with seawater, and this could explain why the Os isotopic composition of sulfides that precipitated above this level has a strong seawater signature. In addition, the massive pyrite zone of the upper part of the sulfide mound formed by processes in which seawater entrainment plays an important role. This zone is formed by accumulation of sulfides that are mainly derived from chimneys and which are part of the fallout material of the hydrothermal plume. Seawater mixing with hydrothermal fluid is the essential mechanism, leading to the formation of sulfide chimneys and to the development of a buoyant hydrothermal plume. The Os in the sulfides precipitating during these two processes should have a clear seawater-derived component.

Using the linear ${ }^{187} \mathrm{Os} /{ }^{186} \mathrm{Os}$ vs. $1 / \mathrm{Os}$ relationship, the Os content of pyrite precipitating from the hydrothermal fluid can be estimated. The Os isotopic composition of the fluid is not well constrained but the comparison of the present data with those of Ravizza et al. (1996) suggests that the ${ }^{187} \mathrm{Os} /{ }^{186} \mathrm{Os}$ value of the fluid should range from about 4.9 to 1.3 . This implies that pyrite precipitating from the fluid contains at least $0.02 \mathrm{ppt}$ Os. Although the partition coefficient of Os between pyrite and hydrothermal fluid is not known, a value of $<1$ is suggested. This is based on observations such as the high Os concentration in some chimney sulfides, the very low concentrations within the hydrothermal system, and the Os enrichment in surrounding sediments, all of which attest to the high mobility of Os in the high temperature hydrothermal system. If the $D_{P y / F l}$ for Os is $<1$, then the hydrothermal fluid contains more than 0.02 ppt Os.

These processes, especially the entrainment of seawater, can also explain the distribution Re within the hydrothermal system. Rhenium is enriched in the stockwork zone ( $\sigma 0 \mathrm{ppb})$ relative to the massive pyrite zone (2-50 ppb), and this distribution can be explained if the behavior of $\mathrm{Re}$ is controlled by the redox conditions. In seawateroxidizing conditions, Re is highly soluble, whereas under reducing conditions it is far less mobile and is concentrated in anoxic sediments. In the TAG hydrothermal system, the interaction of oxidized seawater and reduced hydrothermal fluid appears to be a fundamental process, and the redox conditions are likely determined by the relative proportions of these two media. Deep within the mound, where the hydrothermal fluid component dominates, Re is rather immobile and becomes concentrated. However, in the upper part of the sulfide mound where larger quantities of seawater mix with the fluid, the redox potential could be significantly smaller and Re could be mobilized and released to the ocean.

Further analyses of massive sulfides and sulfide fragments from breccias from deeper stratigraphic levels will help to determine the Os characteristics of the different hydrothermal fluids and will allow an estimate of how much seawater is currently penetrating the hydrothermal system. This in turn could have a profound impact on our current ideas regarding the primary composition of the hydrothermal fluid.

\section{REFERENCES}

Anbar, A.D., Creaser, R.A., Papanastassiou, D.A., and Wasserburg, G.J., 1992. Rhenium in seawater: confirmation of generally conservative behavior. Geochim. Cosmochim. Acta, 56:4099-4103.

Bickle, M.J., and Teagle, D.A.H., 1992. Strontium alteration in the Troodos ophiolite: implications for fluid fluxes and geochemical transport in midocean ridge hydrothermal systems. Earth Planet. Sci. Lett., 113:219-237.

Birck, J.L., and Allègre, C.J., 1994. Contrasting Re/Os magmatic fractionation in planetary basalts. Earth Planet. Sci. Lett., 124:139-148.

Birck, J.L., Roy-Barman. M., and Campos, F., 1997. Re-Os isotopic measurements at the femtomole level in natural samples. Geostand. Newsl., 21.

Brookins, D.G., 1986. Rhenium as an analog for fissiogenic technecium: EhpH diagram (25C, 1 bar) constraints. Appl. Geochem., 1:513-517.

Burton, K.W., Birck, J.-L., Allègre, C.J., Von Blankenburg, F., O’Nions, R.K., and Hein, J.R., 1996. Variations in the osmium isotope ratio of seawater. J. Conf. Abstr., 1:92. 
Chapman, H.J., and Spooner, E.T.C., 1977. ${ }^{87} \mathrm{Sr}$ enrichment of ophiolitic sulfide deposits in Cyprus confirms ore formation by circulating seawater. Earth Planet. Sci. Lett., 35:71-77.

Colodner, D., Sachs, J., Ravizza, G., Turekian, K., Edmond, J., and Boyle E., 1993. The geochemical cycle of rhenium: a reconnaissance. Earth Planet. Sci. Lett., 117:205-221.

Creaser, R.A., Papanastassiou, D.A., and Wasserburg, G.J., 1991. Negative thermal ion mass spectrometry of osmium, rhenium and iridium. Geochim. Cosmochim. Acta, 55:397-401.

Hess, J., Bender, M., and Schilling, J.-G., 1991. Assessing seawater/basalt exchange of strontium isotopes in hydrothermal processes on the flanks of mid-ocean ridges. Earth Planet. Sci. Lett., 103:133-142.

Humphris, S.E., Herzig, P.M., Miller, D.J., et al., 1996. Proc. ODP, Init. Repts., 158: College Station, TX (Ocean Drilling Program).

Humphris, S.E., Herzig, P.M., Miller, D.J., Alt, J.C., Becker, K., Brown, D., Brügmann, G., Chiba, H., Fouquet, Y., Gemmell, J.B., Guerin, G., Hannington, M.D., Holm, N.G., Honnorez, J.J., Itturino, G.J., Knott, R., Ludwig, R., Nakamura, K., Petersen, S., Reysenbach, A.-L., Rona, P.A., Smith, S., Sturz, A.A., Tivey, M.K., and Zhao, X., 1995. The internal structure of an active sea-floor massive sulphide deposit. Nature, 377:713-716.

Koide, M., Hodge, V.F., Yang, J.S., Goldberg, E.G., Calhoun, J., and Bertine, K.K., 1986. Some comparative marine chemistries of rhenium, gold, silver, and molybdenum. Appl. Geochem., 1:705-714.

Lalou, C., Reyss, J.L., Brichet, E., Arnold, M., Thompson, G., Fouquet, Y., and Rona, P.A., 1993. New age data for Mid-Atlantic Ridge hydrothermal sites: TAG and Snakepit geochronology revisited. J. Geophys. Res., 98:9705-9713.

Pegram, W.J., Esser, B.K., Krishnaswami, S., and Turekian, K.K., 1994. The isotopic composition of leachable osmium from river sediments. Earth Planet. Sci. Lett., 128:591-599.

Ravizza, G., Martin, C.E., German, C.R., and Thompson, G., 1996. Os isotopes as tracers in seafloor hydrothermal systems: metalliferous deposits from the TAG hydrothermal area, $26^{\circ} \mathrm{N}$ Mid-Atlantic Ridge. Earth Planet. Sci. Lett., 138:105-119.

Ravizza, G., and Turekian, K.K., 1992. The osmium isotopic composition of organic-rich marine sediments. Earth Planet. Sci. Lett., 110:1-6.

Rona, P.A., 1988. Hydrothermal mineralization at oceanic ridges. Can. Mineral., 26:431-465.
Rona, P.A., Hannington, M.D., Raman, C.V., Thompson, G., Tivey, M.K., Humphris, S.E., Lalou, C., and Petersen, S., 1993. Active and relict seafloor hydrothermal mineralization at the TAG hydrothermal field, MidAtlantic Ridge. Econ. Geol., 88:1987-2013.

Rona, P.A., and Scott, S.D., 1993. A special issue on sea-floor hydrothermal mineralization: new perspectives. Econ. Geol., 88:1935-1975.

Rona, P.A., Thompson, G., Mottl, M.J., Karson, J.A., Jenkins, W.J., Graham, D., Mallette, M., Von Damm, K., and Edmond, J.M., 1984. Hydrothermal activity at the TAG hydrothermal field, Mid-Atlantic Ridge crest at $26^{\circ} \mathrm{N}$. J. Geophys. Res., 89:11,365-11,377.

Roy-Barman, M., 1993. Mesure du rapport ${ }^{187} \mathrm{Os} /{ }^{186}$ Os dans les basaltes et péridotites: contribution à la systematique ${ }^{187} \mathrm{Re}-{ }^{186} \mathrm{Os}$ dans le manteau [Thèse]. Univ. Paris 7.

Roy-Barman, M., and Allègre, C.J., 1994. ${ }^{187}$ Os/ $/{ }^{186}$ Os of mid-ocean ridge basalts and abyssal peridotites. Geochim. Cosmochim. Acta, 58:50435054.

Schiano, P., Birck, J.-L., and Allègre, C.J., 1996. Re-Os isotope systematics of mid-ocean ridge basalt glasses. J. Conf. Abstr., 1:539.

Snow, J.E., and Reisberg, L., 1995. Os isotopic systematics of the MORB mantle. Earth Planet. Sci. Lett., 133:411-421.

Thompson, G., Mottl, M.J., and Rona, P.A., 1985. Morphology, mineralogy and chemistry of hydrothermal deposits from the TAG area, $26^{\circ} \mathrm{N}$ MidAtlantic Ridge. Chem. Geol., 49:243-257.

Tivey, M., Humphris, S.E., Thompson, G., Hannington, M.D., and Rona, P.A., 1995. Deducing patterns of fluid flow and mixing within the TAG active hydrothermal mound using mineralogical and geochemical data. $J$. Geophys. Res., 100:12,527-12,555.

Völkening, J., Walczyk, T., and Heumann, K.G., 1991. Osmium isotopic determinations by negative thermal ionization mass spectrometry. Int. J. Mass. Spectrom. Ion Phys., 105:147-159.

Date of initial receipt: 25 June 1996

Date of acceptance: 8 April 1997

Ms 158SR-209 